\title{
HABITAT AND DISTRIBUTION MODELING OF PREHISTORIC HIPPOS (Hippopotamus sivalensis spp.) DURING PLEISTOCENE IN JAVA ISLAND
}

\begin{abstract}
Andriwibowo $^{1 *}$, Adi Basukriadi ${ }^{2}$, Erwin Nurdin ${ }^{3}$
Selected paper from the $5^{\text {th }}$ Seminar Nasional Biologi (SEMABIO), Bandung-Indonesia, October 8, 2020 (conference.bio.uinsgd.ac.id)

Received : November 20, 2020

Accepted : May 05, 2021

DOI: 10.15575/biodjati.v6i1.10250

1,2,3 Department of Biology, Faculty of Mathematics and Natural Sciences, Universitas Indonesia, Pondok Cina, Beji, Depok, West Java 16424, Indonesia

e-mail:

*1 pemodelandatabio2020@gmail.com ²basukriadi1958@gmail.com 3erwinnurdin0711@gmail.com

*Corresponding author

Abstract. Currently, there are only two extant species of hippos including common (Hippopotamus amphibius) and pygmy hippos (Choeropsis liberiensis). But in prehistoric times, there were several species. During Pleistocene these species were known to migrate to Java Island from Asian Continent and the species was Hippopotamus sivalensis spp. In this regard, this study aimed to model the habitat of H. sivalensis spp., ecology, and biodiversity of Hippopotamus sivalensis spp. based on the fossil record. The model was developed based on the Principal Component Analysis (PCA) method using the $R$ statistical package. The results showed that there were 7 populations of $H$. sivalensis spp. that lived at various altitudes with an average of $177 \mathrm{~m}$ above sea level (95\% CI : 123-232 m). According to PCA, there were at least 2 separate populations of $H$. sivalensis spp. One population occupies the forest while another occupies a habitat close to the coast. Currently the habitat for H. sivalensis spp. already changed. Based on habitat modeling, H. sivalensis spp. inhabit streams with submerged aquatic plants and shrubs and trees growing along river banks.
\end{abstract}

Keywords: Fossil, habitat, hippos, model, PCA, Pleistocene.

\section{Citation}

Andriwibowo, Basukriadi, A. \& Nurdin, E. (2021). Habitat and Distribution Modeling of Prehistoric Hippos (Hippopotamus sivalensis spp.) During Pleistocene in Java Island. Jurnal Biodjati, 6(1), 93-101.

\section{INTRODUCTION}

Currently in the modern era or Anthropocene there are only 2 types of hippos. The two types include the common hippopotamus (Hippopotamus amphibius) and the pygmy hippo (Choeropsis liberiensis) (Bogui et al., 2016). H. amphibious lives in East to South Africa while $C$. liberiensis lives solitary in the rainforests of West Africa. Mammals including hippos have existed for several million years ago. Mammals appeared 35 million years ago along with the existence of plants. The history of the existence of mammals on Java Island began around 1.5 million years ago. The period of fauna existence itself consists of several periods which include Satir (1.5 million), Cisaat (1.2 million), Trinil (1 million), Kedungbrubus (800 thousand), Ngandong (400 thousand), and Punung (100 thousand years ago). It was during the Punung period that modern mammals emerged, such as elephants, tigers, rhinos, gibbons, orang-utans, deer, and long-tailed monkeys (Cranbrook, 2010; Westaway, 2007).

The migration of fauna is thought to 


\section{JURNAL BIDDJATI}

http://journal.uinsgd.ac.id/index.php/biodjati

have originated from Siwalik, Narbada, and Burma via the Siva-Malayan route (De Vos, 1983; Sondaar, 1984; Leinders et al., 1985; Sudijono, 1986). The migration of fauna is supported by the existence of a route connecting the Asian Continent and Java Island along with the decline in sea level in the Sunda Strait at the beginning of the Pleistocene 2.6 million years ago (Aziz, 2000; Fleagle et al., 2010; Suraprasit et al., 2016). The migration of fauna to Java Island includes several types (Siswanto \& Noerwidi, 2016). In Cisaat and Trinil, inhabited by Stegodon trigonocephalus who came via the SivaMalayan route from Siwalik, Narbada, and Burma. Meanwhile, Elephas and Tapirus make up the population of Kedungbrubus and Ngandong. Then in Cisaat and Ngandong, which were inhabited by ancient buffalo.

At the end of the Pleistocene, sea levels continued to decline and gave rise to a wider area of land between the Asian Continent and Java Island. As a result, more species were migrating through this corridor. But in the Holocene era, sea levels rose and fell again and submerged the land between the Asian Continent and the previously formed Java Island. This happened about 12 thousand years ago (Voris, 2000).

In the late Pleistocene, the hippos Hippopotamus sivalensis spp. were also included fauna that migrated to Java Island. Until recently, fossils of Hippopotamus sivalensis spp. have been found in various locations in the central to the east part of Java Island. These species are thought to have lived from the oldest Satir period to Ngandong (400 thousand years ago). Currently, the available data now is only fossil records and lack of ecological studies related to those findings. To complement existing data and knowledge, a habitat, ecology, and biodiversity modeling of Hippopotamus sivalensis spp. on the Java Island is required. Indonesia's archipelago mainly Java Island is enriched with present and past biodiversity as can be seen in faunal fossil deposits. In the present time, this research can contribute to fossil exploration. While for the future, it contributes to the preservation and conservation of prehistoric habitats.

\section{MATERIALS AND METHODS}

For investigating and modeling Hippopotamus sivalensis habitat and ecology in Java Island, two basic principles need to be accomplished following Roebroeks (2006). First is the identification of the spatial pattern based on the hippos presence and absence and then second is explaining such a pattern. The material used to assess the hippos presence was a fossil identified as Hippopotamus sivalensis and fossil specimens were collected through excavation methods following Jukar et al. (2019). Fossil identification reference was based on Boisserie (2005).

The reconstruction of $H$. sivalensis spatial habitat patterns in Java Island was assisted by satellite imaging techniques and on-site observations of this island following methods performed by Bailey et al. (2011). A combination of Landsat satellite images and Shuttle Radar Topographic Mission (SRTM-3) were used and draped on vertically exaggerated digital topography to study the landscape features. On-site observations aimed to record environmental data at each site of the fossil discovery include geographic coordinates, altitude above sea level (asl), macro and micro habitat conditions (in caves, in valleys).

The fossil presence data were then tabulated by including the coordinates and attributes (asl, macro, and micro habitat conditions). Then the data that already has geographic coordinates were mapped using 


\section{JURNAL BIDDJATI}

http://journal.uinsgd.ac.id/index.php/biodjati

a geographic information system (GIS). By overlaying the GIS map, its habitat conditions can be analyzed. For statistical analysis, Principal Component Analysis (PCA) was used using R statistical package (R Core Team, 2013). The purpose of PCA is to assess the correlation of each $H$. sivalensis population at each site and also the attributes that influence the population. Variables to build the PCA included altitude above sea levels (m), distance to coast $(\mathrm{km})$ and habitat (forest, river, valley, cave).

\section{RESULTS AND DISCUSSION}

Initially, Hippopotamus sivalensis was grouped under the Hexaprotodon genus. All species under Hexaprotodon genus have been extinct. Hexaprotodon is characterized by its 6 mandibular incisors and known as hexa. Hexaprotodon was grouped under the Hippopotamus genus because of the difference in the shape of the cranium in the lacrimal part. In addition, $H$. sivalensis also has a different molar arrangement and mandibular shape (Figure 1) (Boisserie, 2005). The most important character of $H$. sivalensis is the orbital bone in the eye which protrudes upwards (Bibi \& Métais, 2016). These characters indicate adaptation to aquatic habitats which are characteristic of the modern hippos of the Hippopotamus genus which has a behavior of submerging in water. Harrison (1997) and Weston (2000) have described in detail the phylogeny of $H$. sivalensis (Figure 2). The Hippopotamus genus split from Hexaprotodon about 6 million years ago. Meanwhile, modern hippos (Hippopotamus amphibious) only existed 3 million years ago.
H. sivalensis itself is estimated to be about 2 $\mathrm{m}$ in length and $1 \mathrm{~m}$ in height (Figure 3 ).

In Java Island, based on the fossil discovery, the existence of $H$. sivalensis spp. was recorded at 7 sites so far and covers a very large area (Figure 4). Areas of habitat for $H$. sivalensis spp. estimated to cover most of East Java bordered with Central Java (1, 2, 3, $5,7)$. Meanwhile, some habitats were found scattered in West (6) and Central Java (4). Table 1 shows the habitat attributes at the sites where the $H$. sivalensis spp. which turned out to vary. $H$. sivalensis spp. found at various altitudes with an average of $177 \mathrm{~m}$ above sea level (95\% CI: 123-232 m).

The PCA analysis (Figure 5) shows habitat variation can affect the diversity of the $H$. sivalensis spp. PCA shows that $H$. sivalensis spp. consisted of 3 populations. The first is the population that is grouped together at sites $2,5,6$, and 7 . The second is the isolated population in site 1 . While the rest are the populations that were located far apart at sites 3 and 4. Population grouping of $H$. sivalensis spp. based on PCA is closely related to the environmental condition of the habitat. There is a separated population as seen at sites 3 and 4 due to the habitat differences of $H$. sivalensis spp. that were varied among populations (Table 1). These differences were related to the fossil exclusively found in the cave whereas $H$. sivalensis spp. was generally found in the valley. Likewise, the $H$. sivalensis spp. populations at sites 3 and 4 occupy habitats close to the coast. But on the contrary $H$. sivalensis spp. was generally occupying inland habitat in the forest far from the coast. 


\section{Jurnal Biodjati 6(1):93-101, May 2021 \\ JURNAL BI@DIATI}

http://journal.uinsgd.ac.id/index.php/biodjati
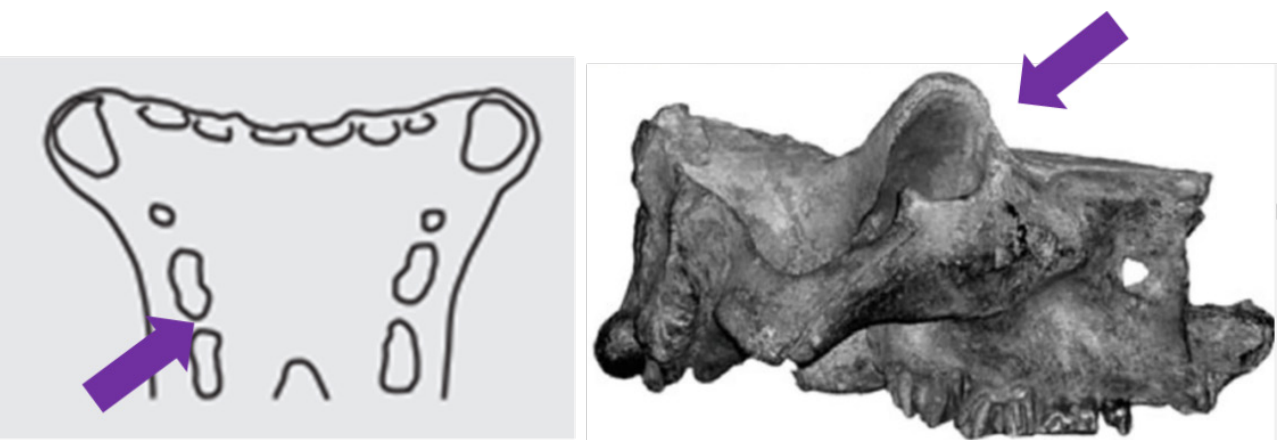

Figure 1. Molar arrangement and the orbital bone in the eye which protrudes upwards observed in H. sivalensis spp. (Boisserie, 2005; Bibi \& Métais, 2016).

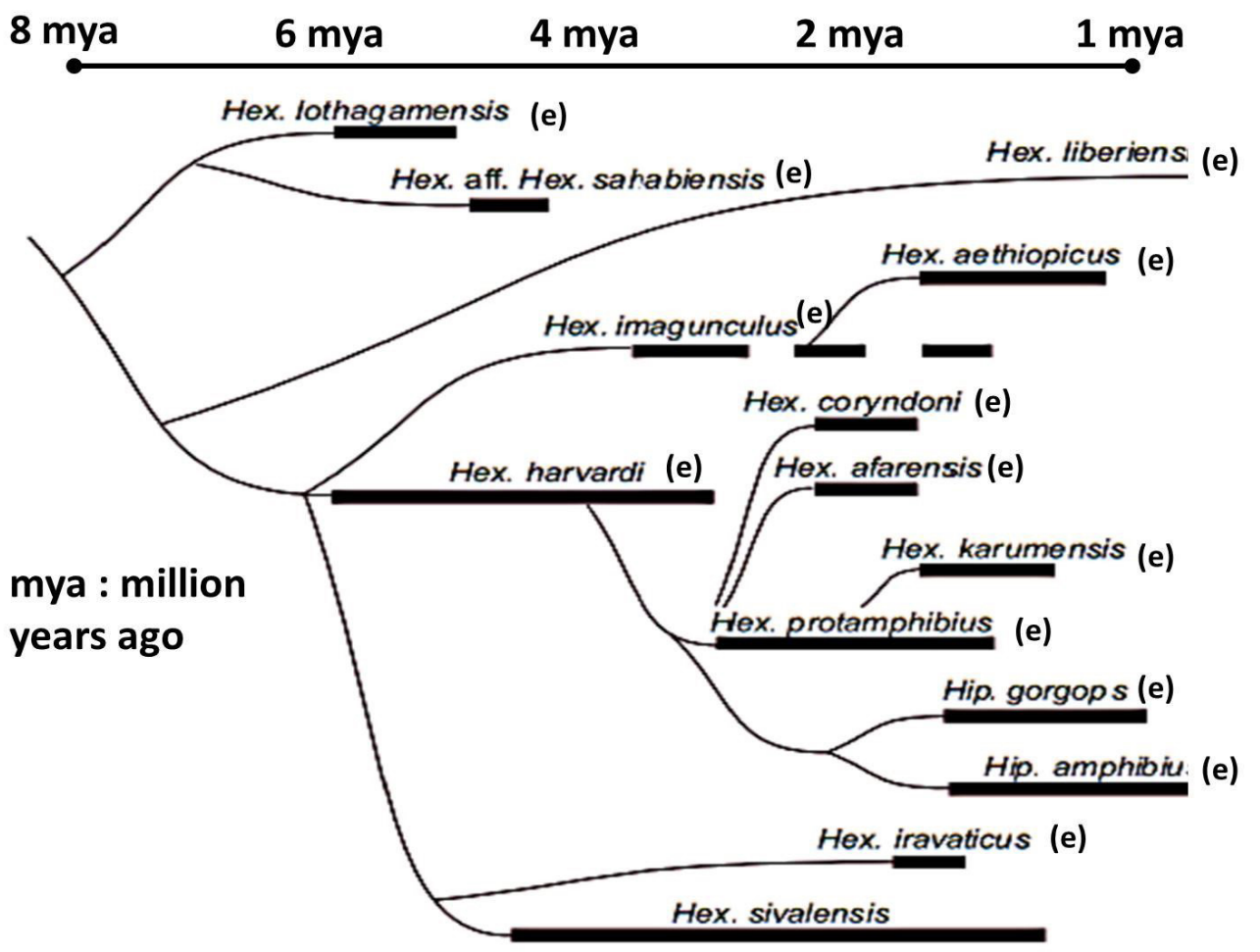

Figure 2. Phylogenetic tree of Hexaprotodon and Hippopotamus ( $\mathrm{e}=$ extinct) from 1 to 8 million years ago (Harrison, 1997; Weston, 2000) 
Jurnal Biodjati 6(1):93-101, May 2021

\section{JURNAL BIDDJATI}

http://journal.uinsgd.ac.id/index.php/biodjati

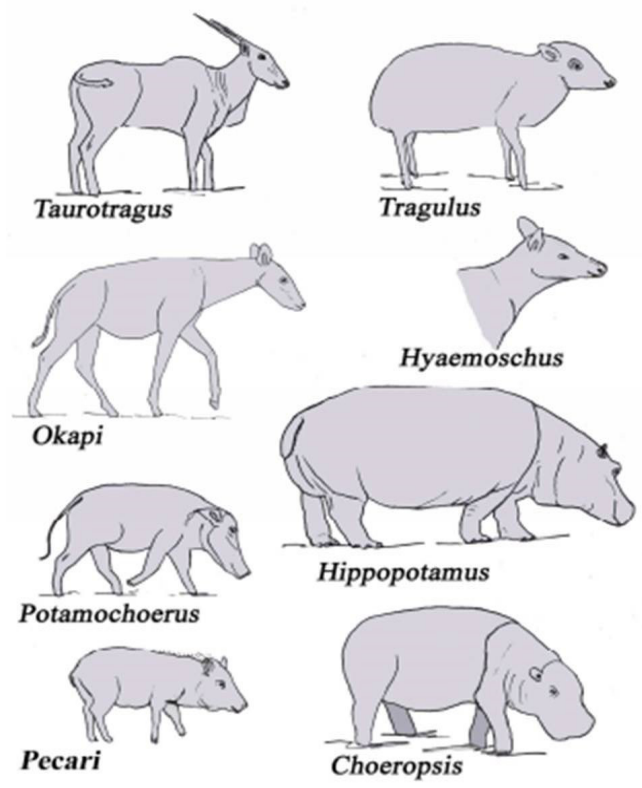

Figure 3. Size comparisons of Hippopotamus with other mammal species (Pickford 2015)

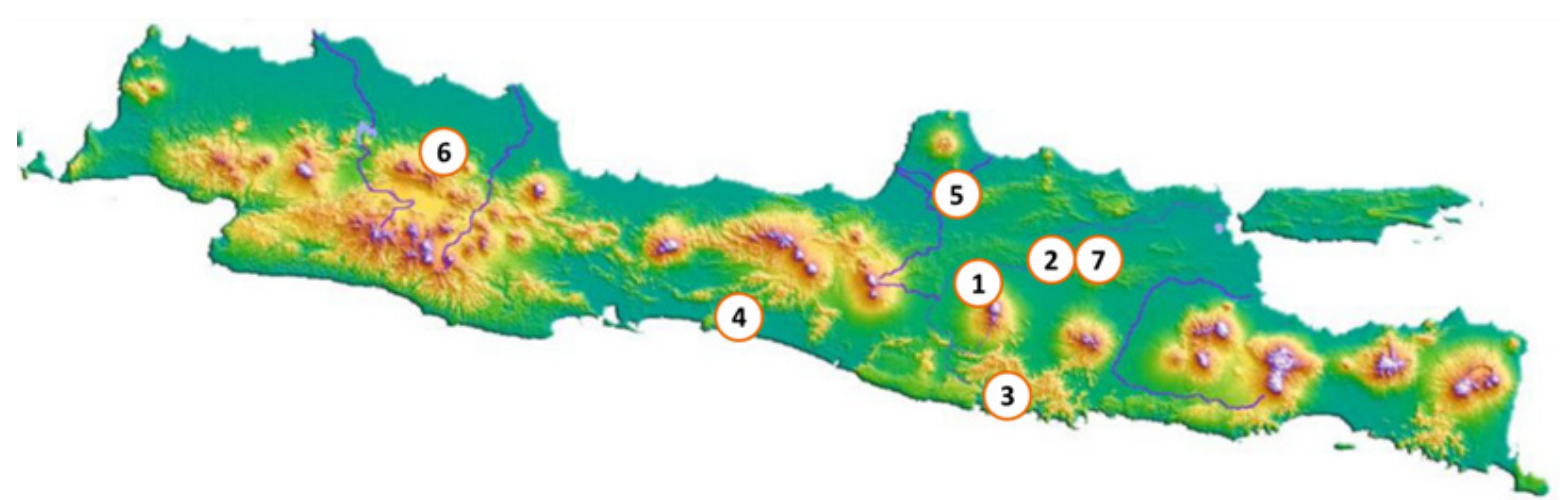

Figure 4. Sites (1-7) where $H$. sivalensis spp. fossils have been found. Sites 1, 2, 5, 6, and 7 were located in forest, valley, and far from the coast. Sites 3 and 4 were located in forest, cave and close to the coast

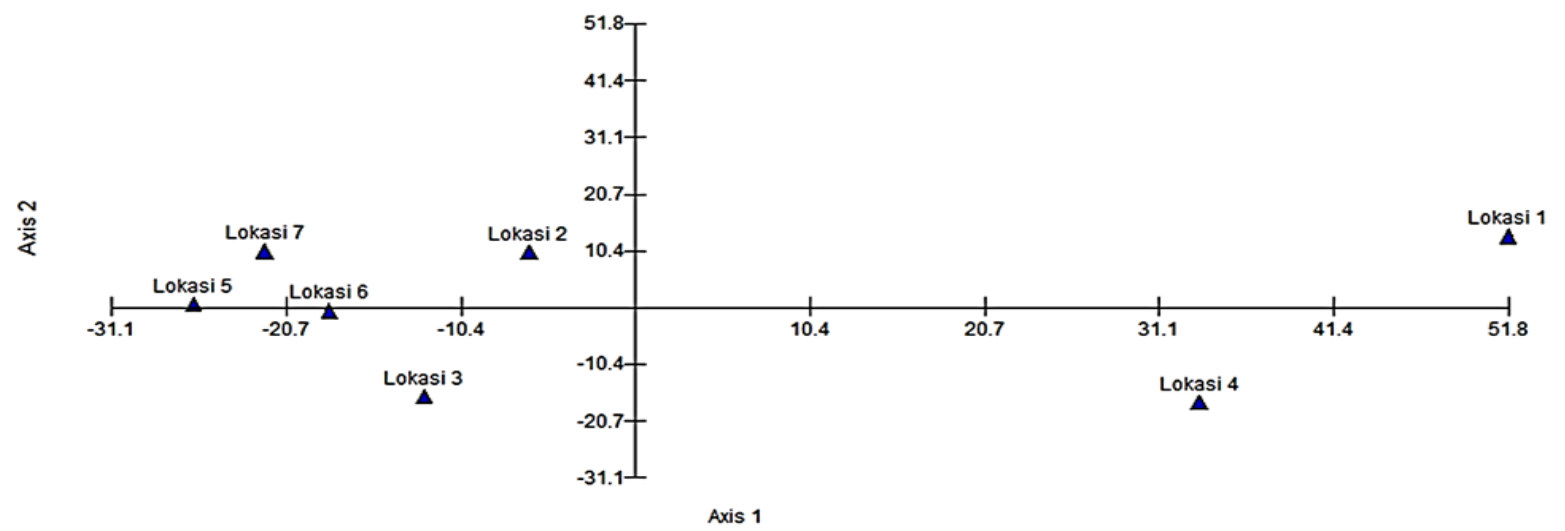

Figure 5. Principal Component Analysis (PCA) of sites 


\section{JURNAL BIDDJATI}

http://journal.uinsgd.ac.id/index.php/biodjati

Table 1. Site characteristics where $H$. sivalensis spp. fossils have been found

\begin{tabular}{|c|c|c|c|c|c|c|c|c|c|}
\hline \multirow{3}{*}{ Site } & \multirow{2}{*}{\multicolumn{2}{|c|}{$\begin{array}{l}\text { Altitude above sea levels } \\
\text { (m) }\end{array}$}} & \multirow{2}{*}{\multicolumn{3}{|c|}{ Distance to coast $(\mathrm{km})$}} & \multicolumn{4}{|c|}{ Habitat } \\
\hline & & & & & & \multicolumn{2}{|c|}{ Macro } & \multicolumn{2}{|c|}{ Micro } \\
\hline & $100-200$ & $201-300$ & $0-30$ & $31-60$ & $61-90$ & Forest & River & Valley & Cave \\
\hline 1 & & $\mathrm{v}$ & & & $\mathrm{v}$ & $\mathrm{v}$ & & $\mathrm{V}$ & \\
\hline 2 & $\mathrm{v}$ & & & & $\mathrm{v}$ & $\mathrm{v}$ & & $\mathrm{v}$ & \\
\hline 3 & $\mathrm{v}$ & & $\mathrm{v}$ & & & $\mathrm{v}$ & & & $\mathrm{v}$ \\
\hline 4 & & $\mathrm{v}$ & $\mathrm{v}$ & & & $\mathrm{v}$ & & & $\mathrm{V}$ \\
\hline 5 & $\mathrm{~V}$ & & & $\mathrm{~V}$ & & $\mathrm{v}$ & & $\mathrm{v}$ & \\
\hline 6 & $\mathrm{~V}$ & & & $\mathrm{v}$ & & $\mathrm{v}$ & & $\mathrm{V}$ & \\
\hline 7 & $\mathrm{v}$ & & & $\mathrm{v}$ & & & $\mathrm{v}$ & $\mathrm{v}$ & \\
\hline
\end{tabular}

The existence of mammals of the same species but occupies different habitats can also be observed in tiger species. Panthera tigris spp. in the Sundarban occupies habitat in swamps while other subspecies live in tropical rainforests. It can also be observed in modern hippos in Africa. For example, $H$. amphibious was occupying open habitats in rivers while $C$. liberiensis lives solitary in rainforests. Possibly $H$. sivalensis spp. on the Java Island does consist of 2 different subspecies. The second possibility is that both populations belong to the same subspecies but there are populations that migrate to the coast. Hippos itself does have a fairly wide home range of 50-500 hectares or a radius of $300 \mathrm{~m}$. While the roaming ability of hippos is known to be quite far too. Even Stears et al. (2019) reported $H$. amphibious walking distance of $15 \mathrm{~km}$. Roth et al. (2004) observed that C. liberiensis was able to travel long distances downstream.

Sites 2, 5, 6, and 7 are also found to be clustered. The grouping is due to the similarity of microhabitats, namely valleys that were previously thought to be the streams. This is also the case with modern hippos. Bogui et al. (2016) reported that the $H$. liberiensis population was found in the middle of forest highland in areas with the presence of rivers. Meanwhile, in sites where there is no river, the hippos population is lower.

Another character that distinguishes sites 3 and 4 is the population of $H$. sivalensis spp. at that sites, it occupies a cave. It is estimated that at that time the sites 3 and 4 were submerged by high tide. Given the Holocene era, seawater rose again and parts of Java Island were once below the surface of the water. This condition causes fauna to take refuge in caves. The next possibility is the presence of $H$. sivalensis spp. in the cave for consumption purposes. According to Dammerman (1932), the existence of various fossils in a cave is because the fauna is consumed as a source of nutrition or ornament by early humans who lived in caves. Even Radiansyah (2010) once found shark teeth in Pawon Cave which is located far from the sea. It is thought that the shark's teeth were taken for decoration.

One of the sites, number 1 , is located in a valley surrounded by hills. But at this time the valley had no river stream and the surrounding vegetation had changed and decreased. Based on the fossil discovery, it is estimated that site 1 used to be a river stream. Figure 6 shows habitat modeling at site 1 some 1.5 million years ago. It is estimated that during the Pleistocene there were still river streams that were overgrown by aquatic plants. While along the edge of the river stream is over- 


\section{JURNAL BIDDJATI}

http://journal.uinsgd.ac.id/index.php/biodjati

grown by shrubs. Towards the land, there is an area overgrown by trees. H. sivalensis spp. prefers habitat in the form of river streams with aquatic vegetation. The vegetation is a food source for $H$. sivalensis spp. and also provides shelter from predators.

To conclude, based on fossil findings, it is estimated that the ancient hippos population was once distributed in parts of East and Central Java. Separate populations were also found occupying coastal habitats and in caves. Currently, all habitats for $H$. sivalensis spp. have undergone a change. $H$. sivalensis spp. was modeled and during Pleistocene it has inhabited streams with submerged aquatic plants and shrubs and trees growing along river banks.

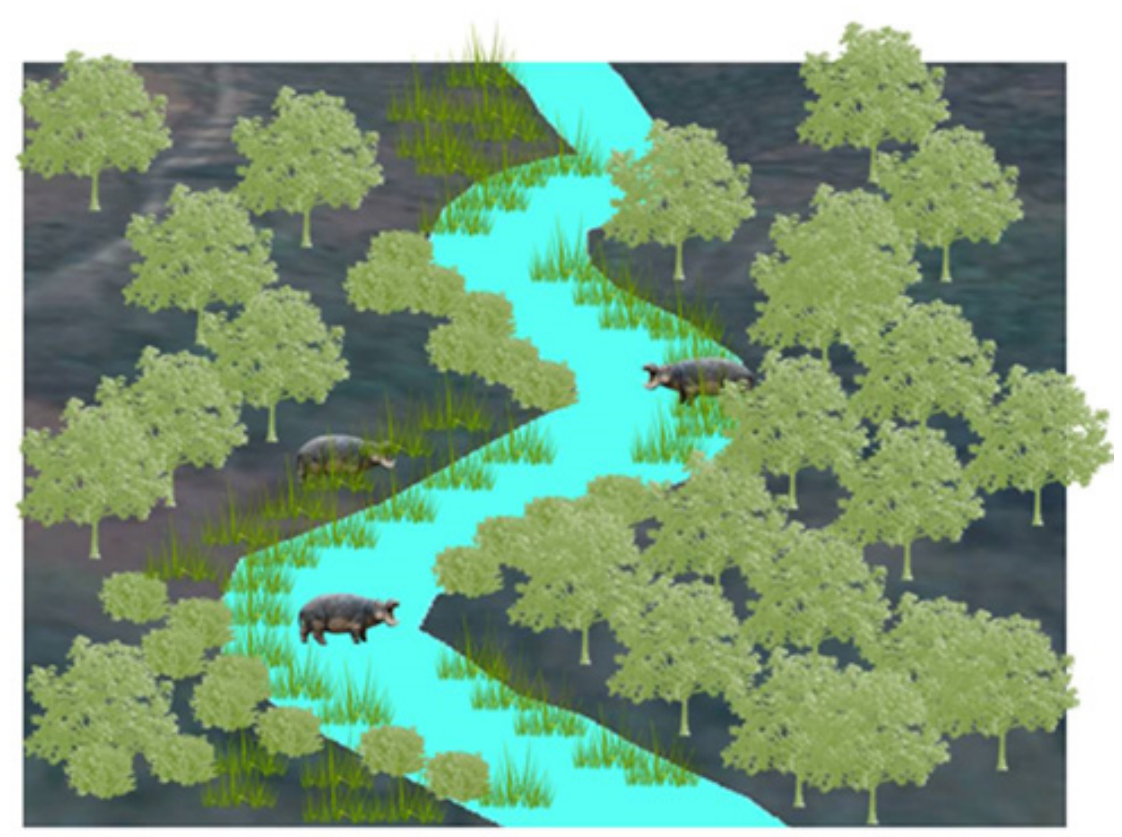

Figure 6. Habitat model in site 1 during Pleistocene 1.5 million years ago with the presences of $H$. sivalensis spp., submerged aquatic vegetation, and woodland

\section{ACKNOWLEDGEMENTS}

We are deeply indebted to the many stakeholders including local community of the site visited and curators that have contributed to the preservations of the fossils and facilitating the excavation process.

\section{REFERENCES}

Aziz, F. (2000). The Pleistocene Endemic Fauna of the Indonesian Archipelago. Tropics, 10(1), 135-143.
Bailey, G. N., Rey, S. C. \& King, G. C. P. (2011). Landscapes of Human Evolution: Models and Methods of Tectonic Geomorphology and the Reconstruction of Hominin Landscapes. J. Hum. Evol., 60(3), 257-280.

Bibi, F. \& Métais, G. (2016). Evolutionary History of the Large Herbivores of South and Southeast Asia (Indomalayan Realm). In The Ecology of Large Herbivores in South and Southeast Asia Ecological Studies (Analysis and Synthesis), vol 225. Dordrecht: Springer. 


\section{JURNAL BIDDJATI}

http://journal.uinsgd.ac.id/index.php/biodjati

Boisserie, J. (2005). The Phylogeny and Taxonomy of Hippopotamidae (Mammalia: Artiodactyla): a Review Based on Morphology and Cladistic Analysis. Zoological Journal of the Linnean Society, 143(1), 1-26.

Bogui, B., Koffi, D.A., Koné, I., Ouattara, K., Kouakou, C. \& Gnagbo, A. (2016). Distribution of Pygmy hippopotamus (Choeropsis liberiensis) in Taï National Park, Ivory Coast : Influences of natural and anthropogenic factors. International Journal of Research in Biosciences, 5(4), 27-35.

Cranbrook, E. (2010). Late Quaternary Turnover of Mammals in Borneo: The Zooarchaeological Record. Biodiversity Conservation, 19, 373-391.

Dammerman, K. W. (1932). On Prehistoric Mammals from the Sampoeng Cave, Central Java. Treubia: a Journal on Zoology of the Indo-Australian Archipelago, 14(4), 477-786.

De Vos, J., Sartono, S., Sasmita, H. S. \& Sondaar, P. Y. (1983). The Pongo Faunas from Java and Sumatra and their Significance for Biostratigraphical and Paleoecological Interpretation. Proc. Kon. Ned lletensch. B., 86(4), 417-425.

Fleagle, J. G., Shea, J. J., Grine, F. E., Baden, A. E. \& Leakey, R. E. (2010). Out of Africa I: The First Hominin Colonization of Eurasia. Vertebrate Paleobiology and Paleoanthropology. Dordrecht: Springer.

Harrison, T. (1997). The Anatomy, Paleobiology, and Phylogenetic Relationships of the Hippopotamidae (Mammalia, Artiodactyla) from the Manonga Valley, Tanzania. In: Harrison T, ed. Neogene paleontology of the Manonga Valley, Tanzania. New York: Plenum Press.

Jukar, A., Patnaik, R., Chauhan, P., Li, H.
C. \& Lin, J.P. (2019). The Youngest Occurrence of Hexaprotodon Falconer and Cautley, 1836 (Hippopotamidae, Mammalia) from South Asia with a discussion on its extinction. Quaternary International, 528, 130-137.

Leinders, M. J. J., Aziz, F., Sondaar, P. Y. \& De Vos, J. (1985). The Age of Hominid Bearing Deposit of Java: State of the art. Geologie en Mijnbouw, 4, I67-173.

Pickford, M. (2015). Encore Hippo-thèses: Head and Neck Posture in Brachyodus (Mammalia, Anthracotheriidae) and its Bearing on Hippopotamid Origins. Communications of the Geological Survey of Namibia, 16, 223-262.

Radiansyah, D. (2010). Gigi Hewan dari Situs Gua Pawon (Jawa Barat): Identifikasi Hewan, Habitat dan Pemanfaatan. Skripsi. Fakultas Ilmu Pengetahuan Budaya, Universitas Indonesia

R Core Team. (2013). R: A language and Environment for Statistical Computing. Vienna, Austria: R Foundation for Statistical Computing.

Roebroeks, W. (2006). The Human Colonisation of Europe: Where are we?. J. Quaternary Sci., 21(5), 425-435.

Roth, H. H., Hoppe-Dominik, B., Mühlenberg, M., Steinhauer-Burkart, B. \& Fischer, F. (2004). Distribution and Status of the Hippopotamids in the Ivory Coast. African Zoology, 39(2) : 211-24.

Siswanto \& Noerwidi, S. (2016). The Faunal Position of Patiayam Site in the Biostratigraphy of Java. SBA, 19(2), 149-166.

Sondaar, P. Y. (1984). Faunal evolution and the Mammalian Biostratigaphy of Java. Coun Forsch. Inst. Senckenberg, 69, 219-235.

Stears, K., Nuñez, T. A. \& Muse, E. A. (2019). Spatial Ecology of Male Hippopotamus in a Changing Watershed. Scientific Re- 


\section{JURNAL BIDDJATI}

http://journal.uinsgd.ac.id/index.php/biodjati

ports, 9:15392.

Sudijono. (1986). Status of the Mammalian Biostratigraphy of Java with Special Sangiran Area. In: ltihara, M. \& T. Kamei., ed., Proceedings of the First Inter. Coll. On reference to the Quarte. Strat. Of Asia Pacific Area 270-289. INQUA, Osaka.

Suraprasit, K., Jaeger, J.J, Chaimanee, Y., Chavasseau, O., Yameem C., Tian, P. \& Panha, S. (2016). The Middle Pleistocene vertebrate fauna from Khok Sung (Nakhon Ratchasima, Thailand): Biochronological and Paleobiogeographical Implications. ZooKeys, 613, 1-157.

Voris, H. (2000). Maps of Pleistocene Sea Levels in Southeast Asia: Shorelines, River Systems and Time Durations. Journal of Biogeography, 27, 1153-1167.
Westaway, K., Morwood., M., Roberts, R., Rokus, A. D., Zhao, J., Storm, P., Aziz, F., Van den Bergh, G., Pradana, H., Jatmiko \& Vos, J. (2007). Age and Biostratigraphic Significance of the Punung Rainforest Fauna, East Java, Indonesia, and Implications for Pongo and Homo. Journal of human evolution, 53(6), 709-717.

Weston, E. M. (2000). A new species of Hippopotamus Hexaprotodon lothagamensis (Mammalia: Hippopotamidae) from the late Miocene of Kenya. Journal of Vertebrate Paleontology, 20(1), 177185. 